\title{
Adiabatic Gasification and Pyrolysis of Coffee Husk Using Air-Steam for Partial Oxidation
}

\author{
Catalina Rodriguez and Gerardo Gordillo \\ Conversion Energy Research Group, Mechanical Engineering Department, Universidad de los Andes, \\ Kr 1 E No. 19A-40, Office ML 652, Bogotá, Colombia \\ Correspondence should be addressed to Gerardo Gordillo, g.gordillo43@uniandes.edu.co
}

Received 30 January 2011; Revised 14 April 2011; Accepted 28 April 2011

Academic Editor: Constantine D. Rakopoulos

Copyright ( 92011 C. Rodriguez and G. Gordillo. This is an open access article distributed under the Creative Commons Attribution License, which permits unrestricted use, distribution, and reproduction in any medium, provided the original work is properly cited.

Colombian coffee industry produces about 0.6 million tons of husk $(\mathrm{CH})$ per year which could serve as feedstock for thermal gasification to produce gaseous and liquid fuels. The current paper deals with: (i) $\mathrm{CH}$ adiabatic gasification modeling using airsteam blends for partial oxidation and (ii) experimental thermogravimetric analysis to determine the $\mathrm{CH}$ activation energy $(E)$. The Chemical Equilibrium with Applications Program (CEA), developed by NASA, was used to estimate the effect of equivalence ratio (ER) and steam to fuel ratio (S:F) on equilibrium temperature and gas composition of $\sim 150$ species. Also, an atom balance model was developed for comparison purposes. The results showed that increased ER and (S:F) ratios produce mixtures that are rich in $\mathrm{H}_{2}$ and $\mathrm{CO}_{2}$ but poor in $\mathrm{CO}$. The value for the activation energy was estimated to be $221 \mathrm{~kJ} / \mathrm{kmol}$.

\section{Introduction}

Combusting fossil fuels produce green house emissions which cause a negative environmental impact. There are various fuel alternative technologies which can be developed in order to mitigate both the dependence on fossil fuels and the negative impact caused by its emissions. Biomass sources, for example, energy crops and wastes, can be used as feedstock in thermal processes such as direct combustion to produce heat, or gasification and pyrolysis to produce gaseous and liquid fuels. The coffee agriculture industry around the world produces a great amount of wastes, for example, only in Colombia about 13 million tons of coffee grain are produced per year, which result in 0.6 tons of coffee husk (see mass balances from coffee processing in Table 1) [1]. These residues can cause pollution of natural sources (land, water, and air) if treatment and storage systems are not correctly managed.

In thermochemical gasification processes biomass feedstock undergoes thermal degradation in an inert medium (pyrolysis, (1)) or partial oxidation in an oxidizing medium (gasification, (2)-(8)) to produce liquid or gaseous fuels, respectively [2]. The oxidizing source can be air, pure oxygen, or a mixture of those with steam. Also, pure steam is used in reforming processes in which the biomass is heated to strip the $\mathrm{H}_{2}$ from the $\mathrm{H}_{2} \mathrm{O}$ through the reaction $\mathrm{C}+$ $\mathrm{H}_{2} \mathrm{O} \rightarrow \mathrm{CO}+\mathrm{H}_{2}$. Subsequently, the produced $\mathrm{CO}$ reacts with the remaining $\mathrm{H}_{2} \mathrm{O}\left(\mathrm{CO}+\mathrm{H}_{2} \mathrm{O} \rightarrow \mathrm{CO}_{2}+\mathrm{H}_{2}\right)$ to produce more $\mathrm{H}_{2}$ and $\mathrm{CO}_{2}$. The gas composition from partial oxidation of biomass depends upon the type of biomass and oxidizing source, as well as on the rate at which both biomass and oxidizer are simultaneously supplied to the gasifier. In general, gasification with air and pure oxygen produces mixtures rich in $\mathrm{CO}$, whereas gasification with airsteam and pure steam produce gases high in $\mathrm{H}_{2}$ [3]. In biomass gasification many reactions occur simultaneously; however, the global process can be modeled using reactions (1) through (8) as shown below [4]:

$$
\begin{gathered}
\mathrm{CH}_{h} \mathrm{O}_{o} \mathrm{~N}_{n}+\text { Heat } \longrightarrow \mathrm{C}+\text { gases, } \\
\mathrm{C}+\mathrm{O}_{2} \longrightarrow \mathrm{CO}_{2}, \quad \Delta \mathrm{H}_{R}=-32765 \mathrm{~kJ} / \mathrm{kg} \text { of } \mathrm{C},
\end{gathered}
$$




$$
\begin{gathered}
\mathrm{C}+\frac{1}{2} \mathrm{O}_{2} \longrightarrow \mathrm{CO}, \Delta \mathrm{H}_{R}=-9205 \mathrm{~kJ} / \mathrm{kg} \text { of C, } \\
\mathrm{C}+\mathrm{CO}_{2} \longrightarrow 2 \mathrm{CO}, \Delta \mathrm{H}_{R}=14360 \mathrm{~kJ} / \mathrm{kg} \text { of C, } \\
\mathrm{CO}+\frac{1}{2} \mathrm{O}_{2} \longrightarrow \mathrm{CO}_{2}, \quad \Delta \mathrm{H}_{R}=-10105 \mathrm{~kJ} / \mathrm{kg} \text { of } \mathrm{CO}, \\
\mathrm{C}+\mathrm{H}_{2} \mathrm{O} \longrightarrow \mathrm{CO}+\mathrm{H}_{2}, \quad \Delta \mathrm{H}_{R}=10930 \mathrm{~kJ} / \mathrm{kg} \text { of } \mathrm{C} \\
\mathrm{CO}+\mathrm{H}_{2} \mathrm{O} \rightarrow \mathrm{CO}_{2}+\mathrm{H}_{2}, \quad \Delta \mathrm{H}_{R}=-1470 \mathrm{~kJ} / \mathrm{kg} \text { of } \mathrm{CO}
\end{gathered}
$$

$$
\mathrm{C}+2 \mathrm{H}_{2} \longrightarrow \mathrm{CH}_{4}, \quad \Delta \mathrm{H}_{R}=-6230 \mathrm{~kJ} / \mathrm{kg} \text { of C. }
$$

Reaction (1) corresponds to any biomass pyrolysis, in which the biomass is heated to volatilize the volatile matter. Subsequently, the products released in pyrolysis $(\mathrm{C}$ and light gases) react with the oxidizer supplied and other gases generated to produce more products (reactions (2) to (8)). Reactions with $\Delta \mathrm{H}_{R}>0$ are endothermic, and those with $\Delta \mathrm{H}_{R}<0$ are exothermic. According to Annamalai and Puri, [5], reaction (2) dominates at low temperatures (below $800^{\circ} \mathrm{K}$ ) while reaction (3) dominates at higher temperatures. In gasification processes, the reactions (4), (6), and (7) are important due to low oxygen and high steam contents in the oxidizing source.

In 2006, Xu et al. [6] reported experimental results on the effects that gasifier temperature, fuel particle size, steam/fuel ratio, residence time, and air supplied to the gasifier have on product gas compositions from gasification coffee grounds. The study was performed in a dual fluidized bed gasifier. In 2009, Gordillo and Annamalai [3] used chemical equilibrium and atom balance modeling to estimate the effect of modified equivalence ratio and $\mathrm{S}: \mathrm{F}$ ratio on the composition of gases produced from air-steam gasification of dairy biomass (DB). In 2009, Velez et al. [7] studied the effect of the steam/fuel ratio on the production of $\mathrm{CO}, \mathrm{H}_{2}$, and $\mathrm{CO}_{2}$ for fluidized bed cogasification of coal with coffee husk. In 2010, Lugano et al. [8] studied the effect of gasification temperature (700, 800 , and $900^{\circ} \mathrm{C}$ ) on coffee husk gasification rate under inert nitrogen conditions and oxygen concentrations ranging between $2 \%$ and $4 \%$. Also, using the fitting kinetics analysis method for a single heating rate $\left(210^{\circ} \mathrm{C} \cdot \mathrm{min}^{-1}\right)$ in a furnace at $900^{\circ} \mathrm{C}$ and the coats approximation algorithm [9], and assuming a reaction model of first order, these researchers estimated the activation energy, $\mathrm{E}$, and the pre-exponential factor, A, of the Arrhenius's equation.

The current paper deals with (i) $\mathrm{CH}$ adiabatic gasification modeling using air-steam blends for partial oxidation and (ii) pyrolysis kinetic model to determine, by thermogravimetric analysis (TGA), the $\mathrm{CH}$ activation energy $(E)$. The Chemical Equilibrium with Applications program (CEA), developed by NASA, was used to estimate the effect of both the equivalence ratio (ER) and steam to fuel ratio ( $\mathrm{S}: \mathrm{F})$ on adiabatic temperature and gas composition of an unlimited number of species $(\sim 150)$, whereas atom
TABLE 1: Mass balance of products obtained from coffee grain pretreatment.

\begin{tabular}{lc}
\hline Part & Percentage $\%$ \\
\hline Red Coffee grain & $100 \%$ \\
Pulp & $43.6 \%$ \\
Mucilage & $14.9 \%$ \\
Water & $17.1 \%$ \\
Husk & $4.2 \%$ \\
Coffee (drink) & $5.8 \%$ \\
Coffee waste & $10.4 \%$ \\
Other & $4.0 \%$ \\
\hline
\end{tabular}

balance was developed to estimate gas composition of a reduced number of species $\left(\mathrm{CH}_{4}, \mathrm{CO}_{2}, \mathrm{CO}, \mathrm{N}_{2}\right.$, and $\left.\mathrm{H}_{2}\right)$ and for comparison purposes. Thermogravimetric analysis (TGA) was carried out using $\mathrm{N}_{2}$ as carrier gas and under different heating rates $\left(\beta: 5,10,20\right.$, and $\left.40^{\circ} \mathrm{C} / \mathrm{min}\right)$, while the isoconversional method (i.e., free model) was used to estimated the activation energy $(E)$.

\section{Adiabatic Gasification Modeling}

The gas composition of the mixtures produced by gasification of biomass can be predicted using chemical equilibrium for a larger number of species or atom balance on components for a reduced number of species $\left(\mathrm{CO}_{2}, \mathrm{CO}\right.$, $\mathrm{CH}_{4}, \mathrm{H}_{2}$, and $\mathrm{N}_{2}$ ). In general, biomass gasification using airsteam mixtures as oxidizing source produces gas mixtures (dry basis) composed mostly by $\mathrm{CO}_{2}, \mathrm{CO}, \mathrm{CH}_{4}, \mathrm{H}_{2}, \mathrm{~N}_{2}$, and other species in trace amounts [3].

2.1. Atom Balance Model. Combustion processes can be classified as complete (stoichiometric), when the reactants undergo complete oxidation, or incomplete, when the reactants do not oxide totally. Equation (9) shows the stoichiometric reaction of any biomass with air as oxidizing source, while (10) presents the incomplete reaction of any biomass with air-steam as oxidizing source. In this last equation, only the most important products are shown

$$
\begin{aligned}
& \mathrm{CH}_{h} \mathrm{O}_{o} \mathrm{~N}_{h} \mathrm{~S}_{s}+a\left(\mathrm{O}_{2}+3.76 \mathrm{~N}_{2}\right) \\
& \quad \longrightarrow b \mathrm{CO}_{2}+c \mathrm{H}_{2} \mathrm{O}+d \mathrm{~N}_{2}+e \mathrm{~S} \\
& \mathrm{CH}_{h} \mathrm{O}_{o} \mathrm{~N}_{h} \mathrm{~S}_{s}+a_{\text {actual }}\left(\mathrm{O}_{2}+3.76 \mathrm{~N}_{2}\right)+x \mathrm{H}_{2} \mathrm{O} \\
& \quad \longrightarrow f \mathrm{CO}_{2}+g \mathrm{CO}+h \mathrm{~N}_{2}+i \mathrm{H}_{2} \mathrm{~S}+j \mathrm{CH}_{4}+k \mathrm{H}_{2} .
\end{aligned}
$$

The equivalence ratio (ER) is a parameter which establishes the ratio between the stoichiometric oxygen and the actual oxygen supplied to the combustor. In the case of gasification with air-steam, the steam to fuel ratio $(\mathrm{S}: \mathrm{F})$ is also an important parameter since it determines the amount of steam supplied to the gasifier per fuel unit. Because both ER and S:F establish the ratio between the rate of biomass and oxidizer supplied simultaneously to the gasifier, they 
have a strong effect on the quality of gases produced. They can be defined as follows:

$$
\begin{gathered}
\mathrm{ER}=\frac{\text { Stoichiometric air moles }}{\text { actual air moles }}=\frac{a}{a_{\mathrm{actual}}}, \\
\mathrm{S}: \mathrm{F}=\frac{\text { Steam moles }}{\text { Fuel moles }}=x .
\end{gathered}
$$

Adiabatic gasification implies equal reactant and product energy. Therefore, the total enthalpy of the reactants (HR), at inlet temperature $\left(T_{\text {in }}\right)$, equals the total enthalpy of the products $(\mathrm{HP})$, at outlet temperature $\left(T_{\text {out }}\right)(13)$

$$
\sum_{j=1}^{m} N_{j} h_{T\left(T_{\text {in }}\right)}=\sum_{i=1}^{n} N_{i} h_{T\left(T_{\text {out }}\right)},
$$

where $N_{j}$ and $h_{T\left(T_{\text {in }}\right)}$ are the moles and total enthalpies of the reactants $j$, at temperature $\left(T_{\text {in }}\right)$, and $N_{i}$ and $h_{T\left(T_{\text {out }}\right)}$ are the moles and total enthalpies of the product $i$, at $T_{\text {out }}$. Using (11) through (13), along with atom balance on components $(\mathrm{C}, \mathrm{H}, \mathrm{O}, \mathrm{N}$, and $\mathrm{S})$, the values of the (8) coefficients $\left(a_{\text {actual }}\right.$, $x, f, g, h, i, j$, and $k$ ) in (10) can be estimated, as a function of the ER, S:F, and $T_{\text {out }}$. The HHV or energy density of the gases produced can be calculated using (14)

$$
\mathrm{HHV}_{\text {gases }}=\sum_{i=1}^{n}\left(X_{i} * \mathrm{HHV}_{i}\right),
$$

where $X_{i}$ and $\mathrm{HHV}_{i}$ are mole fraction and gross heating value $\left(\mathrm{kJ}\right.$ per SATP $\mathrm{m}^{3}$ ) on a dry basis of each fuel gas produced, respectively, $i=\mathrm{CO}, \mathrm{CH}_{4}, \mathrm{H}_{2}$, and so forth, and $\mathrm{HHV}_{\text {gases }}$ is the energy density or HHV (kJ per standard ambient temperature and pressure (SATP) $\mathrm{m}^{3}$ ) of the product gases.

Although the energy density or HHV of the products gives information on the amount of energy per unit of gas produced, it does not provide information on the fraction of energy recuperated as fuel gases per each fuel unit gasified. The fraction of energy recuperated in air-steam gasification processes can be estimated using (15)

$$
\begin{aligned}
& \text { ECE }_{\text {gases }} \\
& =\frac{\operatorname{HHV}_{\text {Gases }}}{N_{\text {Fuel }} * \mathrm{HHV}_{\text {Fuel }}+N_{\text {steam }} * 18 *(\tau+4.18(373-298))},
\end{aligned}
$$

where, $N_{\text {Fuel }}$ and $N_{\text {steam }}$ correspond to the moles of fuel and steam supplied, respectively, to the gasifier by each normal $\mathrm{m}^{3}$ of dry product gases, $\tau$ is the latent heat of steam, $\mathrm{HHV}_{\text {Fuel }}$ is the gross heat value $(\mathrm{kJ} / \mathrm{kmol}$ of DAF fuel) of the fuel, and $\mathrm{ECE}_{\mathrm{Gases}}$ is the energy conversion efficiency (ECE) or energy recovery.

2.2. Chemical Equilibrium Model. The Chemical Equilibrium with Applications program (CEA), developed by NASA, was used under adiabatic conditions to solve for about 150 species (including pure carbon) and adiabatic temperature. The CEA uses chemical equilibrium to estimate the species which are produced from a certain chemical
TABLE 2: Conditions used in atom and equilibrium modeling.

\begin{tabular}{lc}
\hline Parameter & \\
\hline Fuel & Coffee husk $(\mathrm{CH})$ \\
Pressure $($ bar $)$ & 1 \\
Air temperature $\left({ }^{\circ} \mathrm{K}\right)$ & 273 \\
Vapor temperature $\left({ }^{\circ} \mathrm{K}\right)$ & 373 \\
Equivalence ratio $(\mathrm{ER})$ & $1-6$ \\
steam-fuel ratio $(\mathrm{S}: \mathrm{F})$ & $0.3-0.8$
\end{tabular}

reaction. If the reaction is adiabatic, the program requires as input data the reaction pressure and the composition and enthalpy of the reactants. In case of a nonadiabatic reaction, the input data required are the reactant composition and the temperature and pressure of the reaction. Atom and equilibrium models were developed under the conditions shown in Table 2.

\section{Pyrolysis Kinetic Model Based on Thermogravimetric Analysis}

Model-fee and model-fitting have been applied to estimate the kinetics parameters based on thermogravimetric analysis data. In this section a kinetic model based on the isoconversional method (model-free) proposed by Ozawa [10] is presented. This method requires carrying out a series of experiments at different heating rates and assumes basically that the reaction of any solid as shown in (16) is independent of temperature [11]. The reaction rate of solids is usually based on a single step reaction which can be expressed as

$$
\frac{d \alpha}{d t}=A e^{-E / R T} f(\alpha)
$$

where $\alpha$ is the extent of conversion, $t$ is time, $A$ the pre-exponential factor of the Arrhenius's equation, $E$ the activation energy, and $f(\alpha)$ a particular function, called the reaction model, which describes the dependence of the reaction rate on the degree of conversion $\alpha$. The isoconversional method assumes that $A, f(\alpha)$, and $\alpha$ are independent of temperature and that $A$ and $E$ are independent of $\alpha$. Under no isothermal conditions, (16) can be expressed as follows:

$$
\frac{d \alpha}{d T}=\frac{A}{\beta} e^{-E / R T} f(\alpha),
$$

where $\beta=d T / d t$ is the heating rate and $T$ is the temperature. Integrating (17) and taking natural logarithm gives

$$
\begin{gathered}
g(\alpha)=\int_{0}^{\alpha} \frac{d \alpha}{f(\alpha)}=\frac{A}{\beta} \int_{T_{o}}^{T} e^{-E / R T} d T=\frac{A E}{\beta R} f\left(\frac{E}{R T}\right), \\
\ln g(\alpha)=\ln \left(\frac{A E}{R}\right)-\ln \beta+\ln f\left(\frac{E}{R T}\right) .
\end{gathered}
$$


TABLE 3: Ultimate (DAF basis) and proximate analysis of coffee husk biomass.

\begin{tabular}{lc}
\hline & Coffee husk \\
\hline $\mathrm{C} \%$ & 46.51 \\
$\mathrm{H} \%$ & 6.77 \\
$\mathrm{O} \%$ & 46.20 \\
$\mathrm{~N} \%$ & 0.43 \\
$\mathrm{~S} \%$ & 0.09 \\
Ash\% & 0.68 \\
Moisture\% & 7.22 \\
FC\% & 15.5 \\
VM\% & 76.6 \\
HHV $(\mathrm{kJ} / \mathrm{kg})$ & 17945 \\
HHV & 18068 \\
Empirical formula & $\mathrm{kJ} / \mathrm{kg})$ \\
\hline
\end{tabular}

TABLE 4: Conditions used in thermogravimetric analysis.

\begin{tabular}{lc}
\hline Parameter & \\
\hline Atmosphere & Inert $\left(\mathrm{N}_{2}\right)$ \\
Heating rate $\left({ }^{\circ} \mathrm{C} / \mathrm{min}\right)$ & $5,10,20 \mathrm{y} 40$ \\
Final temperature $\left({ }^{\circ} \mathrm{C}\right)$ & 950 \\
Particle size & Lesser than $425 \mu \mathrm{m}$ \\
Repetitions & 2 for each heating rate \\
Sample amount & Lesser than $25 \mathrm{mg}$ \\
\hline
\end{tabular}

Using Doyle's approximation algorithm [12], Equation (19) can be expressed as

$$
\begin{array}{r}
\ln g(\alpha)=\ln \left(\frac{A E}{R}\right)-\ln \beta-5.331-1.052 \frac{E}{R T}, \\
\ln \beta=\ln \left(\frac{A E}{R g(\alpha)}\right)-5.331-1.052 \frac{E}{R T} .
\end{array}
$$

Since $A, E$, and $\beta$ are assumed independent of $T$, the activation energy, $E$, can be estimated from the slope of the linear curves which result of plotting $\ln \beta$ versus $1 / T$ for a constant extent of conversion $(\alpha)$ and the corresponding temperatures of the different heating rates $(\beta)$ [13].

\section{Materials and Methods}

Coffee husk samples were obtained from Colombian coffee industry and were characterized by ultimate and proximate analysis including heating value. Table 3 shows the results from those analyses (DAF basis). The empirical formula was derived using chemical composition and atom balance on compounds. The samples analyzed by thermogravimetric analysis were crushed in order to reduce the particle size to $\leq 425 \mu \mathrm{m}$.

The thermogravimetric analysis was carried out using a NETZSCH STA 409 PC Luxx calorimeter and the software NETZSCH Proteus for MS Windows and under the conditions listed in Table 4.

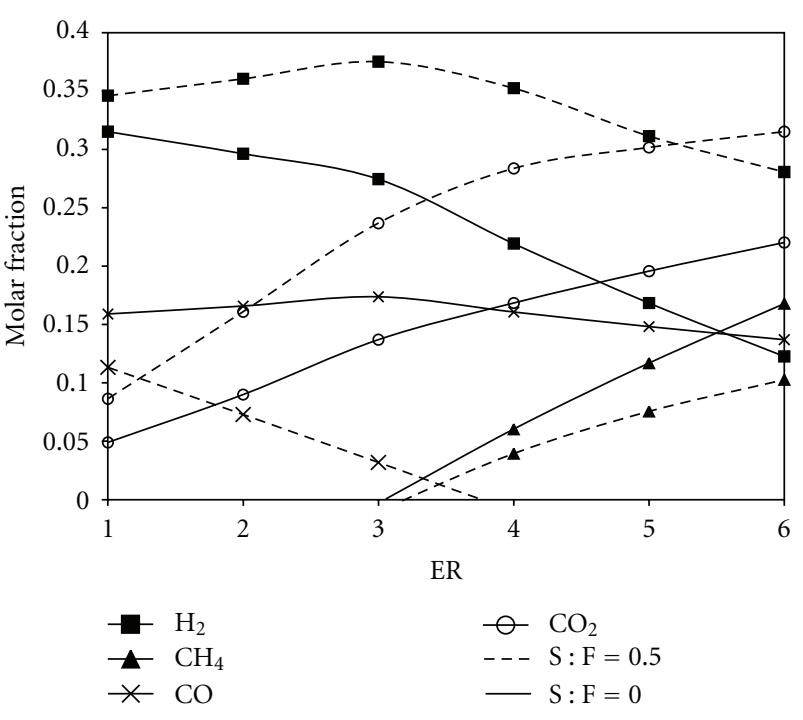

Figure 1: Effect of the ER on the Production of $\mathrm{H}_{2}, \mathrm{CH}_{4}, \mathrm{CO}$, and $\mathrm{CO}_{2}$ for $\mathrm{S}: \mathrm{F}=0, \mathrm{~S}: \mathrm{F}=0.5$, and $T=873 \mathrm{~K}$, estimated by Atom balance model.

\section{Results and Discussion}

5.1. Atom Balance Model. This section discusses the effect of the operating parameters (ER and $\mathrm{S}: \mathrm{F}$ ), estimated by atom balance, on the production of $\mathrm{CO}, \mathrm{CO}_{2}, \mathrm{CH}_{4}$, and $\mathrm{H}_{2}$. Others species such as $\mathrm{N}_{2}$ (present in large amounts) and $\mathrm{H}_{2} \mathrm{~S}$ (and many others present in trace amounts) are not shown.

Figure 1 shows the effect of ER and $\mathrm{S}$ : $\mathrm{F}$ on the $\mathrm{H}_{2}, \mathrm{CH}_{4}$, $\mathrm{CO}$, and $\mathrm{CO}_{2}$ production for a product temperature of $873 \mathrm{~K}$. At constant ER, increasing S : F implies more steam moles in the oxidizer source per each mol of air entering the gasifier; hence, the gasification process occurs in an ambient rich in $\mathrm{H}_{2} \mathrm{O}$, which favors the production of $\mathrm{H}_{2}$ and $\mathrm{CO}_{2}$ via the following reactions: $\mathrm{C}+\mathrm{H}_{2} \mathrm{O} \rightarrow \mathrm{CO}+\mathrm{H}_{2}$ and $\mathrm{CO}+\mathrm{H}_{2} \mathrm{O} \rightarrow$ $\mathrm{CO}_{2}+\mathrm{H}_{2}$. More $\mathrm{C}$ and $\mathrm{H}$ atoms producing $\mathrm{CO}_{2}$ and $\mathrm{H}_{2}$ mean less $\mathrm{C}$ and $\mathrm{H}$ atoms available to produce $\mathrm{CH}_{4}$ and $\mathrm{CO}$, which leads to decreased $\mathrm{CO}$ and $\mathrm{CH}_{4}$ production. From Figure 1, it is apparent that gasification with only air $(\mathrm{S}: \mathrm{F}=$ 0 ) produces more $\mathrm{CO}$ and $\mathrm{CH}_{4}$ and less $\mathrm{H}_{2}$ than gasification with air-steam $(S: F=0.5)$.

5.2. Equilibrium Model. The effects of ER and S:F on adiabatic temperature and gas composition, estimated by equilibrium model, is presented in this section. Although, about 150 species were analyzed, only results on the more relevant species $\left(\mathrm{H}_{2}, \mathrm{CO}, \mathrm{CH}_{4}\right.$, and $\left.\mathrm{CO}_{2}\right)$ are presented here. With exception of $\mathrm{N}_{2}$, other species were in trace amounts. The effect of the ER on adiabatic temperature $\left(T_{\mathrm{ad}}\right)$ is illustrated in Figure 2 for various $S: F$ ratios. At constant $S: F$ ratio, increase in ER results in decrease in the oxygen entering the gasifier; therefore, there are less $\mathrm{O}$ atoms available for the oxidation of $\mathrm{C}$ via the reactions (2) and (3) which are exothermic. Consequently, less heat is released, which leads to lower adiabatic temperatures. Furthermore, the results show that decreased $S: F$ ratios increase the adiabatic 


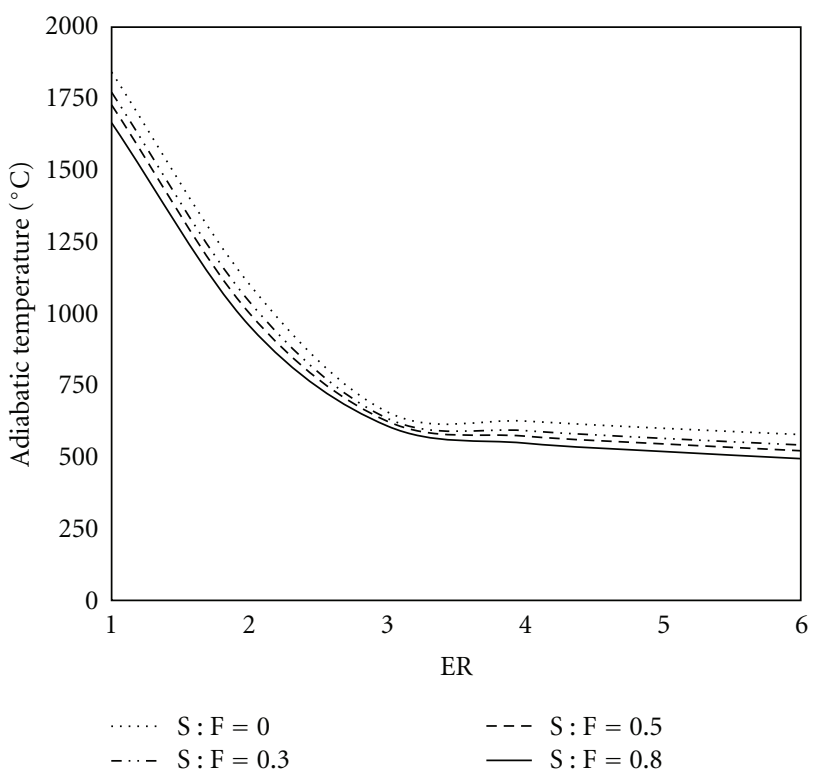

FIGURE 2: Adiabatic temperature estimated with equilibrium model for various $S: F$ ratios, adopted from [14].

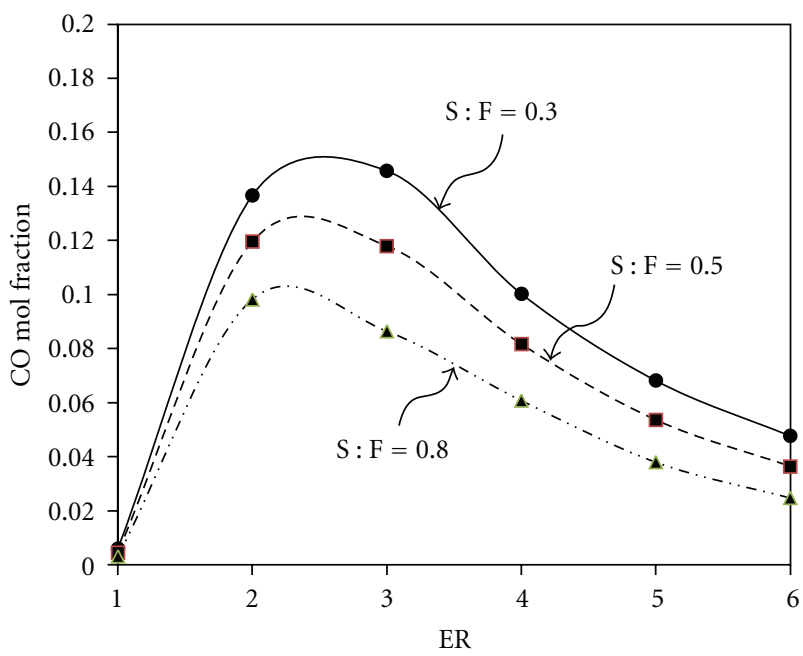

FIGURE 3: Effect of ER on CO production for various $\mathrm{S}$ : F, estimated with chemical equilibrium.

temperature. In general, the maximum temperatures were attained for gasification with only air $(\mathrm{S}: \mathrm{F}=0)$ while the minimum temperatures were obtained at $\mathrm{S}: \mathrm{F}=0.8$. At $\mathrm{ER}>$ 3.5 the effect of the ER on $T_{\text {ad }}$ is negligible. This suggests that gasification of $\mathrm{CH}$ at $\mathrm{ER}>3.5$ tends to be pure pyrolysis.

Figures 3, 4, 5, 6 show the effect of ER, on $\mathrm{CO}, \mathrm{CO}_{2}$, $\mathrm{H}_{2}$, and $\mathrm{CH}_{4}$ for various $\mathrm{S}: \mathrm{F}$. At constant $\mathrm{S}: \mathrm{F}$, higher ERs imply less oxygen entering the gasifier for the reaction $\mathrm{C}+$ $(1 / 2) \mathrm{O}_{2} \rightarrow \mathrm{CO}$; thus, there are more $\mathrm{C}$ atoms available to react with the steam to produce $\mathrm{H}_{2}$ via the reaction $\mathrm{C}+$ $\mathrm{H}_{2} \mathrm{O} \rightarrow \mathrm{CO}+\mathrm{H}_{2}$. The $\mathrm{CO}$ produced by the reactions of $\mathrm{C}$ with steam and $\mathrm{C}$ with oxygen reacts with the remaining steam to produce more $\mathrm{H}_{2}$ and $\mathrm{CO}_{2}$ (shift reaction). More $\mathrm{C}$

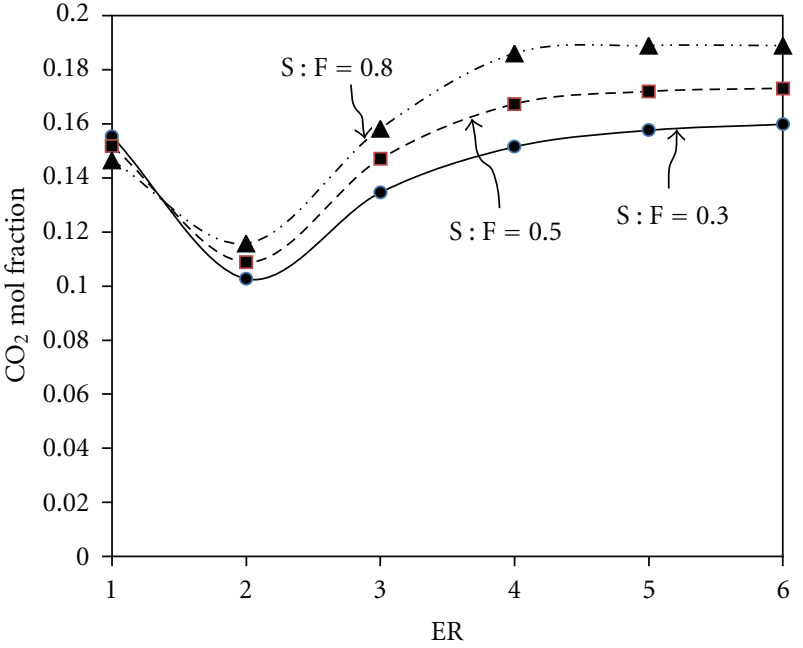

Figure 4: Effect of ER on $\mathrm{CO}_{2}$ production for various $\mathrm{S}: \mathrm{F}$, estimated with chemical equilibrium.

atoms consumed by the shift reaction $\left(\mathrm{CO}+\mathrm{H}_{2} \mathrm{O} \rightarrow \mathrm{CO}_{2}+\right.$ $\mathrm{H}_{2}$ ) imply less $\mathrm{C}$ atoms leaving as $\mathrm{CO}$.

The $\mathrm{CO}$ and $\mathrm{H}_{2}$ curves show a peak with the ER (Figures 3 and 5). The CO mole fraction increases with increased ER until $\mathrm{ER} \cong 2.5$ beyond which it starts to decrease. The lowest value of $\mathrm{CO}$ is reached at $\mathrm{ER}=1$ (stoichiometric reaction) while the maximum $(\sim 16 \%)$ is attained at $\mathrm{ER} \cong 2.5$ and $\mathrm{S}: \mathrm{F}=0.30$ (Figure 3 ). The concentration of $\mathrm{H}_{2}$ also shows an inflection point at $\mathrm{ER}=3.2$. At $\mathrm{ER}<3.2$, increased ER increases very strongly the concentration of $\mathrm{H}_{2}$ but at ER > 3.2, and the effect of the ER on the fraction of $\mathrm{H}_{2}$ is rather weak (Figure 5). Although, the effect of $\mathrm{S}: \mathrm{F}$ on the $\mathrm{H}_{2}$ concentration is insignificant the results suggest that the steam-to-air ratio entering the gasifier affects the $\mathrm{H}_{2} / \mathrm{CO}$ ratio leaving the gasifier. At constant $\mathrm{S}: \mathrm{F}$, increasing the ER (decreased oxygen supplied through air) increases steamto-air ratios. From these results, it is evident that higher $\mathrm{S}$ : F ratios increase the $\mathrm{H}_{2} / \mathrm{CO}$ ratio. At $\mathrm{ER}<2$, the $\mathrm{CO}_{2}$ decreases with increased ER and S:F ratios whereas at ER > 2.0 increasing both ER and S:F produces mixtures rich in $\mathrm{CO}_{2}$. This is because of the higher steam concentration in the reactor, which favors the reaction of $\mathrm{CO}$ with steam (shift reaction) to produce more $\mathrm{H}_{2}$ and $\mathrm{CO}_{2}$. As shown in Figure 6, more available $\mathrm{H}$ atoms in the gasifier lead to $\mathrm{CH}_{4}$-rich concentrations. From Figure 6, it is evident that at $\mathrm{ER}<3.3$, the effect of the S:F ratio on the concentration of $\mathrm{CH}_{4}$ is practically negligible and that the production of $\mathrm{CH}_{4}$ is only possible at $\mathrm{ER} \gtrsim 2.0$. In general, these results show that at ER $<2.0$ (increased oxygen through air), the concentration of $\mathrm{CO}$ and $\mathrm{H}_{2}$ increases and that the concentration of $\mathrm{CO}_{2}$ and adiabatic temperature decrease with increased ER (Figure 3 through 6), indicating that the heterogeneous $\mathrm{C}+\mathrm{H}_{2} \mathrm{O} \rightarrow \mathrm{CO}+\mathrm{H}_{2}$ reaction (which is endothermic, $\Delta \mathrm{H}_{R}=10,390 \mathrm{~kJ} \mathrm{~kg}^{-1}$ of C) is more important than the homogeneous $\mathrm{CO}+\mathrm{H}_{2} \mathrm{O} \rightarrow \mathrm{H}_{2}+\mathrm{CO}_{2}$ reaction, which is a slightly exothermic $\left(\Delta \mathrm{H}_{R}=-1470 \mathrm{~kJ} \mathrm{~kg}^{-1}\right.$ of CO). At $2.0<\mathrm{ER}<3.0$ (less $\mathrm{O}_{2}$ supply), the shift reaction begins to 


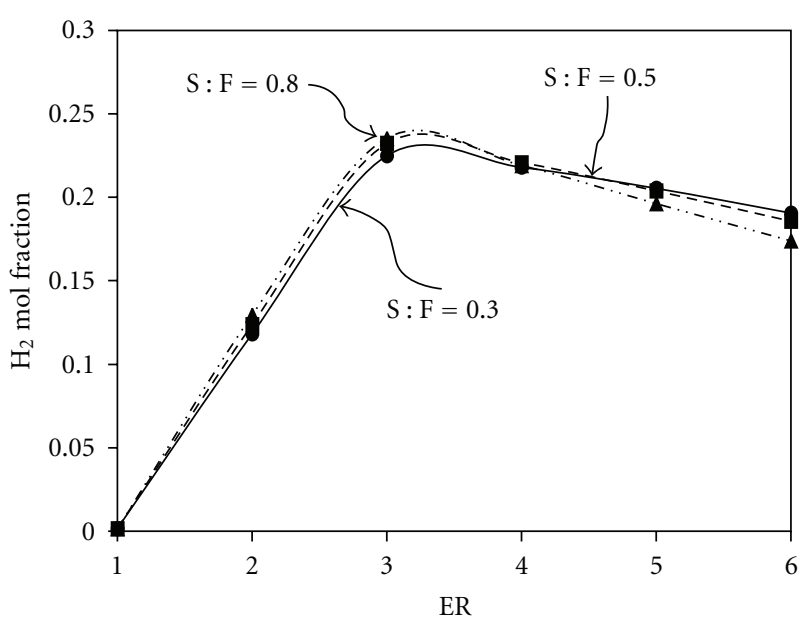

FIGURE 5: Effect of ER on $\mathrm{H}_{2}$ production for various $\mathrm{S}$ : $\mathrm{F}$, estimated with chemical equilibrium.

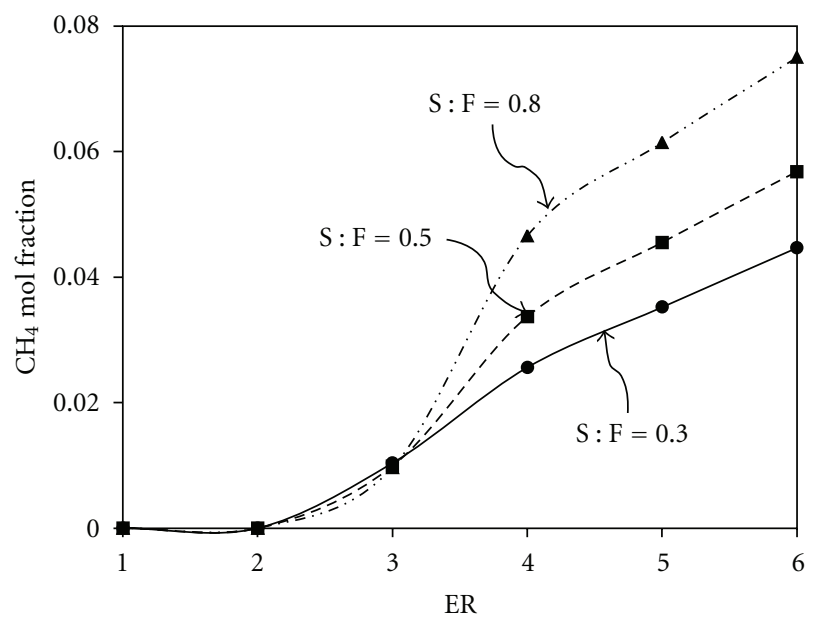

FIGURE 6: Effect of ER on $\mathrm{CH}_{4}$ production for various $\mathrm{S}: \mathrm{F}$, estimated with chemical equilibrium.

be important because the $\mathrm{H}_{2} \mathrm{O}$ concentration in the reactants is much higher. Hence, $\mathrm{CO}$ production starts to decrease whereas the production of $\mathrm{H}_{2}$ increases.

The molar fraction of carbon estimated with equilibrium model is presented in Figure 7 as a function of ER and various $S: F$. It is evident that the production of carbon (C) is possible only at ER $>3$. This suggests that at those ER the oxygen supplied is not enough to burn completely the carbon atoms through the reactions (2) and (3). On the other hand, at constant $\mathrm{S}: \mathrm{F}$ and $\mathrm{ER}>3$, increasing ER increases carbon production, because of the less oxygen supplied for each $\mathrm{kg}$ of fuel gasified. Also, the results show that at constant ER, increased $\mathrm{S}: \mathrm{F}$ ratios produce lower carbon indicating that the more $\mathrm{H}_{2} \mathrm{O}$ in the reactant react with char. In general, the results on $\mathrm{C}$ production indicate that at $\mathrm{ER}>3$ the pyrolysis tend to be important.

The results from chemical equilibrium modeling and atom modeling are compared in Table 5 showing that the

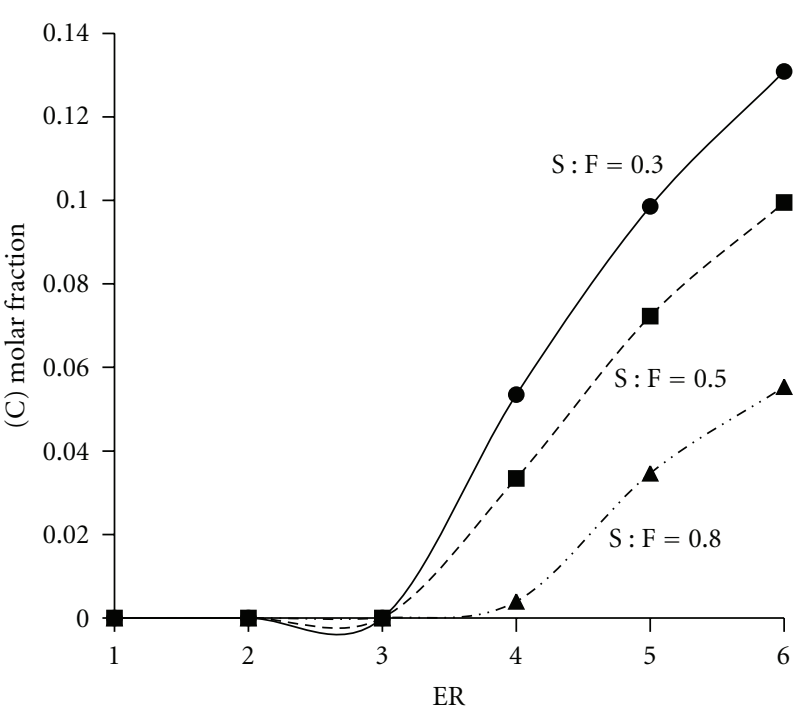

FIGURE 7: Effect of ER on Char (C) production for various S:F, estimated with chemical equilibrium.

gas composition (except $\mathrm{CH}_{4}$ and $\mathrm{CO}$ ), predicted with atombalance and equilibrium model are almost similar. The difference in $\mathrm{CH}_{4}$ and $\mathrm{CO}$ is due to the fact that the equilibrium model includes a larger number of species $(\sim 150)$ compared to atom balance that includes the production of only 6 species $\left(\mathrm{CO}, \mathrm{CO}_{2}, \mathrm{CH}_{4}, \mathrm{H}_{2}, \mathrm{~N}_{2}\right.$, and $\left.\mathrm{H}_{2} \mathrm{~S}\right)$. The lower amount of species estimated with atom balance is due to the lower number of available equations. Also, due to the low number of species, atom balance supposes that all the fixed carbon (FC) contained in $\mathrm{CH}$ and all $\mathrm{H}$ atoms contained in both $\mathrm{CH}$ and oxidizer reacts completely, through the reactions (2), (3), (4), (6), and (8), to produce the secondary products (CO, $\mathrm{CH}_{4}, \mathrm{CO}_{2}$, and $\mathrm{H}_{2}$ ) shown in the global reaction (10). Thus, there is no presence of $\mathrm{C}$ and $\mathrm{H}_{2} \mathrm{O}$ in the products. However, equilibrium model includes in the products pure carbon (Figure 7) and $\mathrm{H}_{2} \mathrm{O}$.

5.3. HHV of Gases. Table 6 presents the energy density of the gases at $2<\mathrm{ER}>6$ and $0.3<\mathrm{S}: \mathrm{F}<0.8$. At $\mathrm{ER} \leq 3.0$, increasing $\mathrm{S}: \mathrm{F}$ decreases the HHV. In contrast, at ER $>3$, the HHV of gaseous fuel increases with increased $S: F$ ratios. As discussed earlier, increased $\mathrm{S}: \mathrm{F}$ decreases the production of $\mathrm{CO}$ (Figure 3); thus, the HHV tend to decrease. Although, at $\mathrm{ER}>3$, increasing $\mathrm{S}: \mathrm{F}$ decrease $\mathrm{CO}$, the gas HHV increases due to more production of $\mathrm{CH}_{4}$ (Figure 6) which has a higher HHV ( $38000 \mathrm{~kJ} / \mathrm{SATP})$ as compared to that of the CO $\left(\sim 11000 \mathrm{~kJ} / \mathrm{SATP} \mathrm{m}^{3}\right)$. In general, at constant $\mathrm{S}: \mathrm{F}$, increasing the ER tends to increase the HHV. The HHV for the selected operating conditions varied from 2643 to $5037 \mathrm{~kJ} / \mathrm{SATP} \mathrm{m} 3$. The highest HHV $\left(5037 \mathrm{~kJ} / \mathrm{SATP} \mathrm{m}^{3}\right)$ was achieved for a $\mathrm{ER}=6$ and $\mathrm{S}: \mathrm{F}=0.80$, whereas the lowest HHV $(2643 \mathrm{~kJ} / \mathrm{SATP} \mathrm{m} 3)$ was attained at ER $=2$ and $\mathrm{S}: \mathrm{F}=$ 0.8 . From Table 6, it is evident that the effect of ER ratio on gas $\mathrm{HHV}$ is stronger than that of the $\mathrm{S}: \mathrm{F}$.

Table 7 presents the energy conversion efficiency (ECE) estimated with equilibrium model for the range of operating 
TABLE 5: Comparison of results on gas composition (mole fraction on a dry basis) obtained by atom and equilibrium model, adopted from [14].

\begin{tabular}{lcccccc}
\hline & & $\mathrm{S}: \mathrm{F}=0$ & & \multicolumn{2}{c}{$\mathrm{S}: \mathrm{F}=0.5$} \\
& Chemical equilibrium & Atom balance & Difference $(\%)$ & Chemical equilibrium & Atom balance & Difference $(\%)$ \\
\hline Temp. $\left({ }^{\circ} \mathrm{K}\right)$ & 873 & 873 & 0.06 & 873 & 3.22 & 0.02 \\
$\mathrm{ER}$ & 3.74 & 3.73 & 0.27 & 0.0017 & 3.23 & 0.16 \\
$\mathrm{CH}_{4}$ & 0.045 & 0.044 & 2.76 & 0.024 & 0.002 & 0.022 \\
$\mathrm{CO}$ & 0.163 & 0.164 & 0.85 & 0.252 & 0.253 & 0.373 \\
$\mathrm{CO}_{2}$ & 0.162 & 0.161 & 0.65 & 0.377 & 0.39 \\
$\mathrm{H}_{2}$ & 0.232 & 0.234 & 0.88 & & 0.377 \\
\hline
\end{tabular}

TABLE 6: HHV of gases $\left(\mathrm{kj} / \mathrm{SATP} \mathrm{m}^{3}\right)$.

\begin{tabular}{cccccc}
\hline S:F & & \multicolumn{5}{c}{ ER } \\
& 2 & 3 & 4 & 5 & 6 \\
\hline 0.30 & 2956 & 4687 & 4632 & 4413 & 4396 \\
0.50 & 2823 & 4431 & 4742 & 4649 & 4642 \\
0.80 & 2643 & 4095 & 4948 & 4957 & 5037 \\
\hline
\end{tabular}

TABLE 7: Energy conversion efficiency (ECE) estimated with equilibrium model.

\begin{tabular}{cccccc}
\hline S:F & & \multicolumn{5}{c}{ ER } & \\
& 2 & 3 & 4 & 5 & 6 \\
\hline 0.30 & 0.61 & 0.81 & 0.71 & 0.65 & 0.60 \\
0.50 & 0.56 & 0.75 & 0.72 & 0.66 & 0.62 \\
0.80 & 0.49 & 0.67 & 0.72 & 0.68 & 0.56 \\
\hline
\end{tabular}

parameters studied $(2<\mathrm{ER}<6$ and $0.3<\mathrm{S}$ : $\mathrm{F}<0.8)$. Even though at ER $>3$ the energy density of the gases increases with increased ER, ECE decreases with increased ER. This is because under those operating conditions $(\mathrm{ER}>3)$ there is more production of carbon and the gasification tends to be near pyrolysis that produces lesser amount of combustible gases and more combustible loss through char. On the other hand, at ER $<3$, increased ER tends to increase the ECE. For the range of the operating conditions studied, ECE ranged from 0.56 to 0.81 ; the remaining fraction corresponds to the energy returned in char and sensible heat of gases leaving the gasifier.

The results on gas composition and ECE show that the highest productions of $\mathrm{H}_{2}(23 \%)$ and $\mathrm{CO}(\sim 15 \%)$ and the highest ECE $(81 \%)$ are achieved at $\mathrm{ER}=3$ and $\mathrm{S}: \mathrm{F}=0.3$, which suggests that those are the best operating conditions.

5.4. Kinetics Model. This section presents results obtained from the kinetic analysis. Figure 8 illustrates the thermogravimetric analysis (TGA) of the coffee husk pyrolysis for four different heating rates $\left(5,10,20\right.$, and $\left.30^{\circ} \mathrm{C} / \mathrm{min}\right)$. Also, in Figure 8, the different conversion degrees $(\alpha: 20,30,40$, and $50 \%$ ) used to estimate the activation energy (E) are pointed out.

The mass released between $300^{\circ} \mathrm{K}$ and $400^{\circ} \mathrm{K}$ corresponds to the moisture content $(\sim 7.5 \%)$ in $\mathrm{CH}$. On the other hand, the results from Figure 8 indicate that most of the

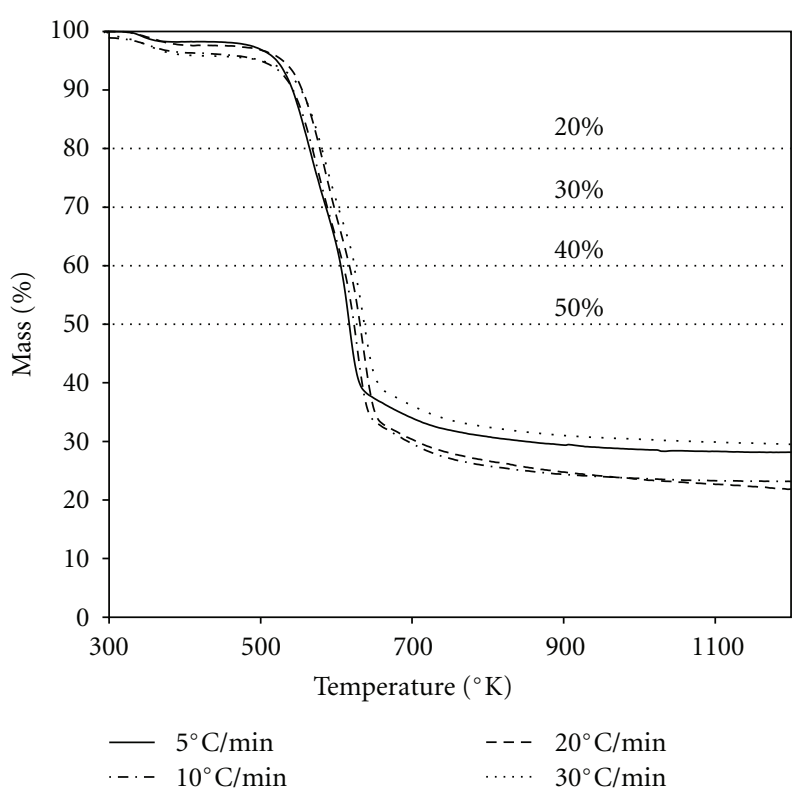

FIGURE 8: Thermogravimetric analysis of the coffee husk pyrolisys at different heating rates, adapted from [14].

volatile matter (VM) content in $\mathrm{CH}$ is volatilized between $\sim 500 \mathrm{~K}$ and $700 \mathrm{~K}$ (higher slope of the curves). After $\sim 700 \mathrm{~K}$, the mass tends to remain constant, indicating that most of this mass corresponds to char (fixed carbon and ash contents in HC biomass). In general, the results from TGA show that the volatilization of VM is very important at $500 \mathrm{~K}<T<$ 700. Conversely, at $T>700 \mathrm{~K}$ the rate of VM released is negligible, which indicates that the $\mathrm{CH}$ pyolysis process occurs at temperatures ranging between 500 and $700 \mathrm{~K}$.

Figure 9 shows the plots of $-\ln \beta$ versus $10^{-3} \mathrm{~T}$ for conversion degrees $(\alpha)$ of $20,30,40$, and $50 \%$ and the corresponding heating rates $(\beta)$ of $5,10,20$, and $40^{\circ} \mathrm{C} \cdot \mathrm{min}^{-1}$. The activation energy was estimated from the slopes of linear curves which match the experimental results.

Table 8 illustrates the slopes and the activation energies of the thermal decomposition kinetics of $\mathrm{CH}$ for different conversion degrees. Also, the arithmetic average of all conversion degree studied and the standard deviation are presented.

The average activation energy discussed here for the $\mathrm{CH}$ pyrolysis $(211 \mathrm{~kJ} / \mathrm{kmol})$ is higher than those presented by 
TABLE 8: Slope, correlation coefficient, and activation energy obtained from 9 for various conversion degrees, adapted from [14].

\begin{tabular}{lccccc}
\hline Conversion $(\%)$ & Slope & $R^{2}$ & $E(\mathrm{~kJ} / \mathrm{mol})$ & $E_{\text {average }}(\mathrm{kJ} / \mathrm{mol})$ & \\
\hline 20 & 33.99 & 0.82 & 273.15 & & 221 \\
30 & 30.64 & 0.71 & 245.09 & & 46.87 \\
40 & 24.84 & 0.70 & 196.71 & & \\
50 & 21.58 & 0.81 & 169.02 & & \\
\hline
\end{tabular}

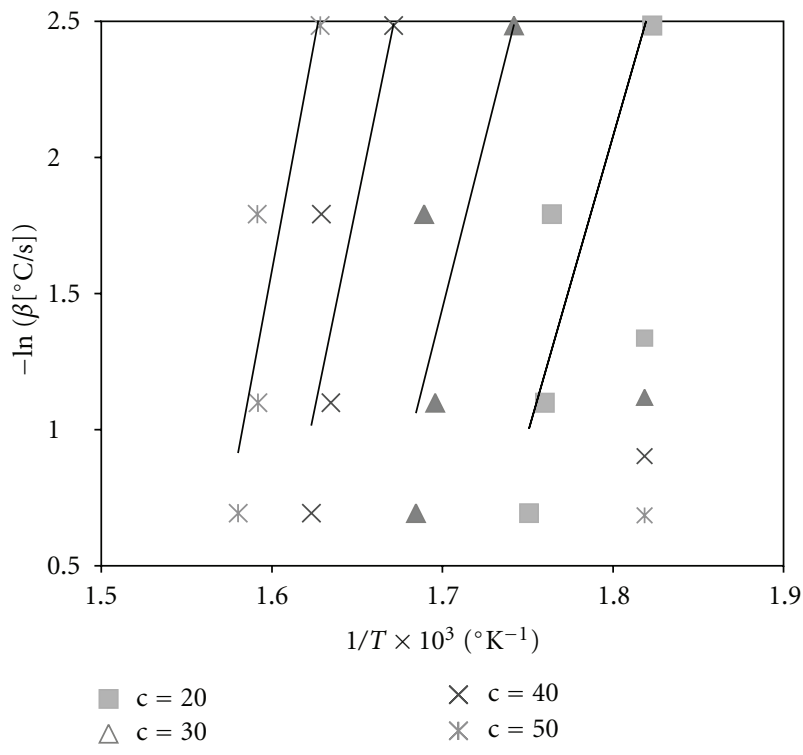

Figure 9: Curves to determine the activation energy of $\mathrm{CH}$, based on the kinetic model proposed by [13], for various conversion degrees, adapted from [14].

Lugano et al. [8] for $\mathrm{CH}(161 \mathrm{~kJ} / \mathrm{kmol})$ and Sanchez et al. [15] for combustion of biowastes $(143 \mathrm{~kJ} / \mathrm{kmol})$, but it is a little lower than that presented by Garcia-Pèrez et al. [16] for sugarcane bagasse pyrolysis $(235 \mathrm{~kJ} / \mathrm{kmol})$. The difference between the value of the activation energy presented here and that presented by Lugano et al. [8] is due to the use of different methods to estimate E. In this study, the isoconversional (free) method was used for different heating rates $\left(5,10,20\right.$, and $\left.30^{\circ} \mathrm{C} / \mathrm{min}\right)$, while Lugano et al. [8] used the fitting method for a single heating rate $\left(210^{\circ} \mathrm{C} / \mathrm{min}\right)$. Also, the fitting method, for a single heating rate, requires assuming previously a particular function $(f(\alpha))$, which depends on the reaction's mechanism, in order to estimate the activation energy, whereas the isoconversional method (i.e., free-model) does not require assuming previously any particular function to estimate the activation energy.

\section{Conclusions}

The results suggest that gasification of $\mathrm{CH}$ with air-steam could produce gaseous combustibles with $\mathrm{H}_{2}$ concentrations from 0 to $\sim 25 \%$, $\mathrm{CO}$ from 0 to $\sim 16 \%$, and $\mathrm{CH}_{4}$ from 0 to $\sim 7 \%$.

Equilibrium temperature decreases with increased ER until $\mathrm{ER}=3.5$. At $\mathrm{ER} \gtrsim 3.5$, the effect of $\mathrm{ER}$ on equilibrium temperature is negligible, indicating that under these operating conditions the process tend to be near pyrolysis.

Increased ER increases both the production of $\mathrm{CO}$ until $\mathrm{ER} \cong 2.5$ after which it starts to decrease and the production of $\mathrm{H}_{2}$ until $\mathrm{ER} \cong 3.2$ after which it tend to be constant, indicating that at ER > 3.2 the effect of the ER on the fraction of $\mathrm{H}_{2}$ is rather weak.

In general, increasing $\mathrm{S}: \mathrm{F}$ ratio tends to produce richer mixtures in $\mathrm{CO}_{2}$ and $\mathrm{CH}_{4}$ but poorer in $\mathrm{CO}$. On the other hand, the effect of the $\mathrm{S}: \mathrm{F}$ on the $\mathrm{H}_{2}$ production is negligible.

The activation energy of the $\mathrm{CH}$ pyrolysis $(211 \mathrm{~kJ} / \mathrm{kmol})$ is higher than those presented by $[8,15]$ for $\mathrm{CH}$ and combustion of biowastes, respectively, but it is a little lower than that presented by [16] for sugarcane bagasse pyrolysis $(235 \mathrm{~kJ} / \mathrm{kmol})$. The difference between the activation energy presented here and that presented by [8] is due to the use of different method to estimate it. According to [11], the kinetics parameters of the Arrhenius's equation, estimated using the fitting method, are different to these estimated using the free method.

\section{References}

[1] Federación Nacional de Cafe teros de Colombia, 2004-2008, 2009, http://www.cafedecolombia.com/cafe/index.html.

[2] D. L. Klass, Biomass for Renewable Energy, Fuels, and Chemicals, Academic Press, San Diego, Calif, USA, 1998.

[3] G. Gordillo and K. Annamalai, "Adiabatic fixed-bed gasification of coal, dairy biomass, and feedlot biomass using an airsteam mixture as an oxidizing agent," Renewable Energy, vol. 34, no. 12, pp. 2789-2797, 2009.

[4] G. Gordillo and K. Annamalai, "Gasification of coal and dairy manure with air-steam as oxidizing agent," in Proceedings of the ASME/JSME Thermal Engineering Summer Heat Transfer Conference, Vancouver, Canada, July 2007.

[5] K. Annamalai and I. Puri, Combustion Science and Engineering, CRC Press, Boca Raton, Fla, USA, 2007.

[6] G. Xu, T. Murakami, T. Suda, Y. Matsuzawa, and H. Tani, "Gasification of coffee grounds in dual fluidized bed. Performance evaluation and parametric investigation," Energy \& Fuels, vol. 20, no. 6, pp. 2695-2704, 2006.

[7] J. F. Velez, F. Chejne, C. F. Vades, E. J. Emeridy, and C. A. Londono, "Co-gasification of Colombian coal and biomass in fluidized bed: an experimental study," Fuel, vol. 88, no. 3, pp. 424-430, 2009.

[8] W. Lugano, J. R. Geoffrey, M. F. Cuthbert, Y. Weihong, and B. wlodzimierz, "Coffee husks gasification using high temperature air/steam agent," Fuel Processing Technology, vol. 91, no. 10, pp. 1330-1337, 2010.

[9] A. W. Coats and J. P. Redfern, "Kinetics parameters from thermogravimetric data," Nature, vol. 201, pp. 68-69, 1964. 
[10] T. Ozawa, "A new method of analyzing thermogravimetric data," Bulletin of the Chemical Society of Japan, vol. 38, pp. 1881-1886, 1965.

[11] S. Vyazovkin and C. A. Wight, "Model-free and model-fitting approaches to kinetic analysis of isothermal and nonisothermal data," Thermochimica Acta, vol. 340-341, pp. 53-68, 1999.

[12] C. D. Doyle, "Estimating isothermal life from thermogravimetric data," Journal of Applied Polymer Science, vol. 6, pp. 639-642, 1962.

[13] J. H. Flynn and L. A. Wall, "A quick, direct method for the determination of activation energy from thermogravimetric data," Polymer Letters, vol. 4, pp. 323-328, 1966.

[14] C. Rodriguez, "Análisis termogravimétrico del bagazo de la caña de azúcar y de la cascarilla de café para la estimación de las constantes cinéticas en los procesos de gasificación," Universidad de los Andes, Thesis, 2009.

[15] M. E. Sanchez, M. Otero, X. Gomez, and A. Moran, "Thermogravimetric kinetic analysis of the combustion of biowastes," Renewable Energy, vol. 34, no. 6, pp. 1622-1627, 2009.

[16] M. Garca-Pèrez, A. Chaala, J. Yang, and C. Roy, "Copyrolysis of sugarcane bagasse with petroleum residue. Part I: thermogravimetric analysis," Fuel, vol. 80, no. 9, pp. 1245-1258, 2001. 

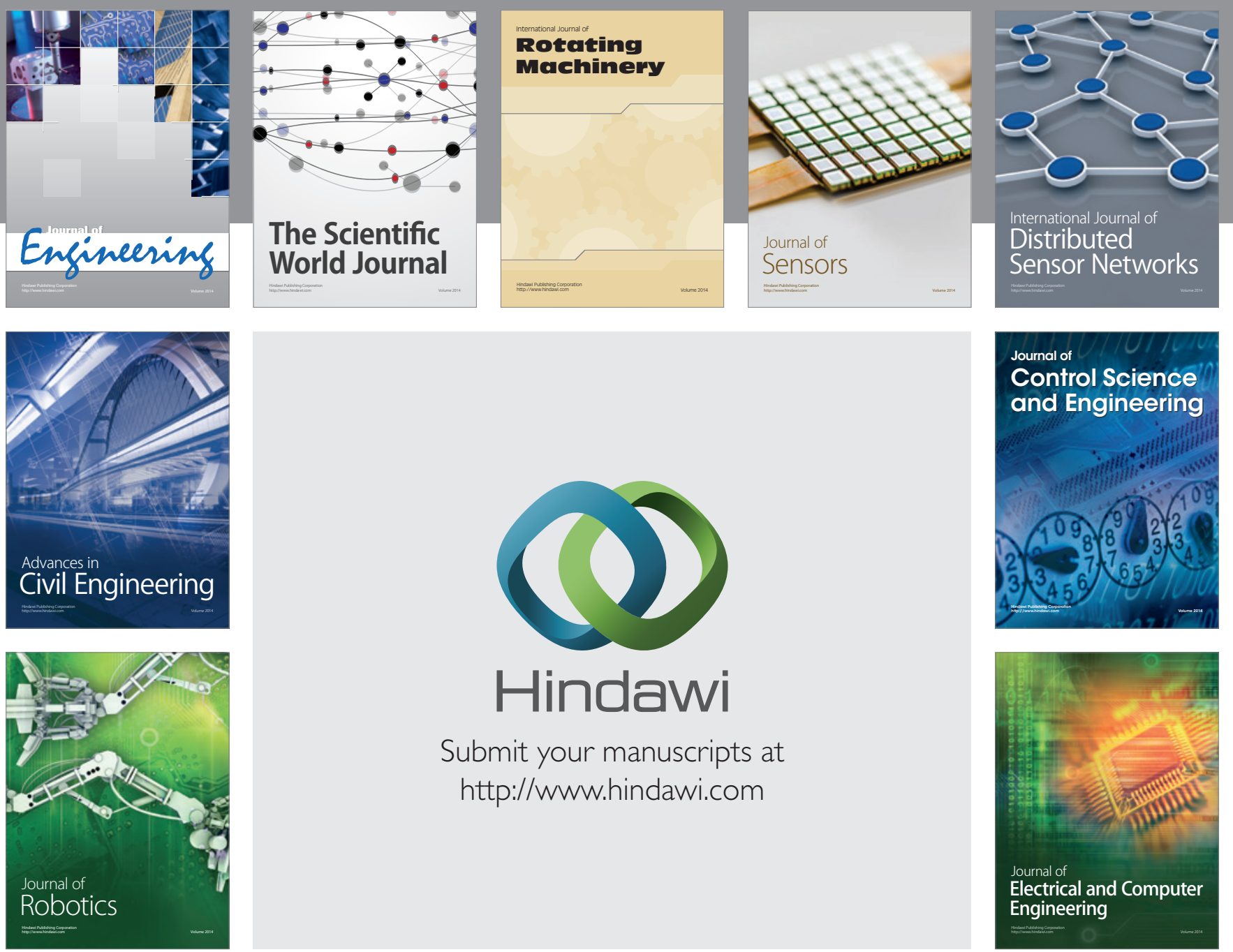

Submit your manuscripts at

http://www.hindawi.com
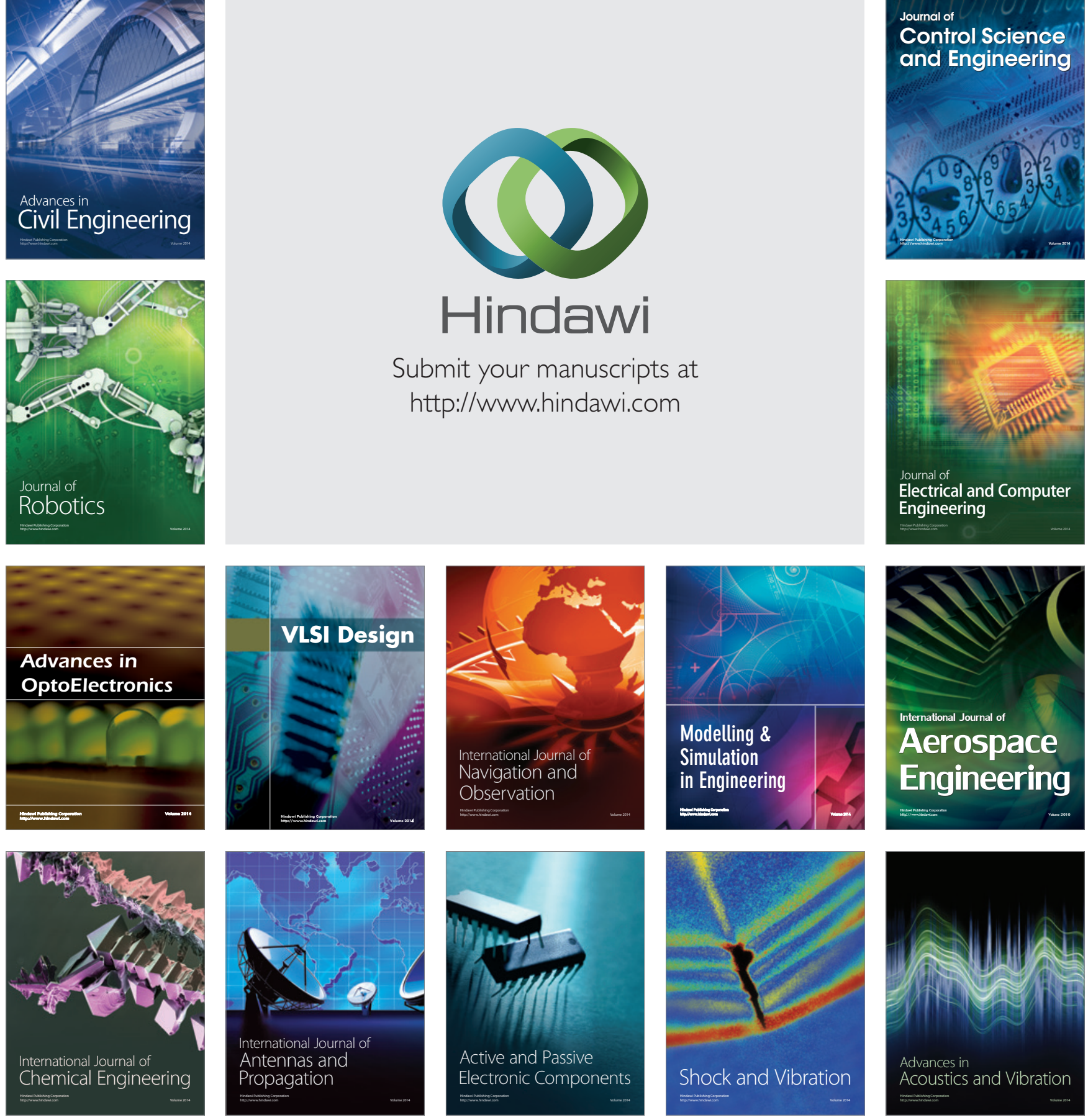